\title{
PATHOLOGICAL AND BACTERIOLOGICAL INVESTIGATION ON TRAUMATIC INJURIES IN THE CARCASSES OF SLAUGHTERED CAMELS
}

\author{
Altabar, G.; Gameel, A. A." and Hatem, M. E. \\ College of Vetertnay Mediclne and AnImal Regources. \\ KIng Falsal Untversity. P.O Box 1757, AL-Hasga 31982. SaudI Arabla
}

\begin{abstract}
A total of 569 camel carcasses were examined at Al-Ahsa abattoir for the presence of traunatic injurles. 136 carcasses had injuries in the thigh muscles (77.9\%). rump (19.5\%), hump (5.1\%), thonacic muscies (2.9\%) and flank reglon (2.2\%). Most of the injures were in the form of contustons (81\%) but necrasis and suppwation were also observed in the rump and thigh. In three cases, fistulation was occurred in sublumbar muscles. Histologically, contused muscles shouved edema and ischaemte necrosis asscclated with sevene homorrhages. Necrotic muscles showed hyallne degeneration and zerker's necrosis associaled with mild inflammatory cell reaction. Suppurative myostts characterized by marked fibroplasins was seen th the severely affected mus cles. Surface swabs taken from the traumatized parts and the corresponding unaffected parts were cultured for aerobtc and anaerobtc bacteria. The isolated normal microflora identifled as : Enterobacter agglomerans, Enierobacter sakazakit, Sernatia odorffera, Serratia marcescens, Aeromonas hydrophlla, Mlcroconcus species and Lavtobacitlus specles. The bacterlal populations were estmated by higher counts on the iryured surfaces as compared to their unaffected surfaces. Some pathogentc bacteria and fungi were recovered from the surface of troumatized parts and identyferd as saimonella Anzzora, Staphyloconcus aureus, Klebslello pneumonae, Pasteurella haemolyttca. Streptococcus feculis, Conynebactertum pseudotuberculosis. Candida albicans and aspergillus flauss. The bacterial counts did not exceed $10 \mathrm{CFU} / \mathrm{cm}^{2}$.. but the levels encountered may constitute a potential source of meat spollage. The pathogenk bacteria and fungi isolated may have a publc health significance.
\end{abstract}

\section{INTRODUCTTON}

Traumatic lesions can be inflicted on camels durlng foeding. fightling transportation. chasing and restraint. Hitting and poking of animals, by owners or animal attendants, usIng sticks and mecal bars may cause sertous skin and skeletal infurles which may range from haemorrhagle contusions to phlegmonous intlammation and necrosls. Such injuries may act as a portal or entry for opportuniatic organlsms which may cause tissue damage and lead to meat spoilage (Altabarl, 2009; Graces and Collins. 1990; Gregory and Grandin, 1998; Bega- 
novic, 1978; Jerzembec, 1977; McGavia et al., 2001; Wtison, 2000).

The present study describes pathological and bactertological changes associatcd with traumattc Injurtes in camel carcasses at ANAhsa abattolr-Eastenz reglon of Saudl Arabla.

\section{MATERUALS AND METHODS}

Weekly vistts were pald to Al-Ahsa abattoir. Slaughtered camel carcasses were examined carefully for prescnce of skejetal infurtes or any other gross abnormalltes. Stte of injury and dimensions of injured areas werc recorded and lesions were described.

\section{Bacterlologlcal Methods :}

Swabs were taken from the traumatzed surfaces as well as from the corresponding uninjured parts (controls). after evisceration and before washing and ecolling of careasses. using standard techniques (Downer and Kelth, 2004; speck, 1884). The swabs were preserved in $10 \mathrm{ml}$ peptone water. Ten folded sertal dilatons were made and cullured In appropriate medla using the Dripe Plate Method and noubated aeroblcally at 30, 37 and $44^{\circ} \mathrm{C}$ for 48-96 hours. The plates were then read using a colony counter. Smears were made and stuined with Gram's stain. Blochemical characteristics of the lsolated ralcroorganlans werc determined by using API $20 \mathrm{E}$ Bio Merieux Systern for bactertal identufication (Dwighte et al.,2004; Jay et al,2006; Koneman et al., 1992).

\section{Pathologlical Methods :}

Samples from Injured Ussuc were tuxed in $10 \%$ formalin, processed in paramn and sections (4pm thick) were prepared and stained with haenatoxylin and cosin (HE).

\section{RESUTTS}

Careage examination:

A total or 569 camels of both sexes, about 10-14 year old, were examined. Out of them. 136 (23.9\%) carcasses showed traumatle injuries in the thigh, rump, hump, chest and lank regions (Table 1). Most injurtes were in the form of contustons whteh had dufferent shape (round, oval. roughly rectangular and other Irregular shapes) appeared edematous and haemorrhagic. Muscle necrosis was observed in the thigh muscles In 7 cases while phlcgmonous inflammation was seen in the rump regions of two others (Figures 1-5). The latter extended internally through a nstula to lrivolve the lumbar mubcles. One case showed abscesses in lliac lymph nodes, uterus and peritoneal cavtty which necessitated total carcass condemriation. The surface area of the contused and necrotic sites can be seen In Table 2. Most contustons, espectally in thigh and rump regions had surface area of $50 \mathrm{~cm}$. or less. The depth of leslons ranged from 1 to $3 \mathrm{em}$.

\section{Elatopathological Ending :}

Contused muscles appeared homogenous and strueture less and in many places obscured by extenstve haemorrhages. Subculaneous thsue showed edema and marked hae. morrhages. Necrolic muscles showed loss of strtations, pyknotic nuclel and some haemorrhages. Inflammatory call reaction was not a distinct feature. Some sections showed typlcal Zenkers necrosls. The areas of phlegmonous inflammation showed marked muscle necrosks and fbrosis with extenstve inflarnmatory cell inflitration (MacGarin et al.. 2001), predoml- 
nantly neutrophils (Figures 6 \& 7 ).

\section{Bacterlological findinge :}

The mcan mesophillc bacterlal counts can be seen in Table 3 . The counts on the contused surfaces were about four-fold those on the corresponding untnjured parts, $1.0 \times 10$ and $2.7 \times 10_{-}$bacterla $/ \mathrm{cm}_{\sim}$ respectlvely. MIcracoccus spectes were the masl numerous and were isolated from all sampled surfaces. followed by Laclobacllus. Enterobacter and Scrratla specles.

Several pathogente bacterta were also Isolated, matnly from the thigh and rump reglons. Salmonella, Klcbsiella, Staphylococcus. Pasteurelia. Protcus and Corynebacterium organlsms were only recovered from injured sites wbille Streptococeus faecalls was Isolated from both injured and uninjured surfaces.

The mean counts for yeast and moulds on the contused surfaces $(1.7 \times 10 / \mathrm{cm})$ were about 18-Fold those on the conresponding unaffected parts $(0.9 \times 10 / \mathrm{cm})$. Candida alblcans, Aspergllus havis and Mucor specles wcre identifled.

\section{DISCUSSION}

Undue force may be exerted on antmals durlng transportation, especlally when load. ing and unloading or whlle anlmals are driver to new premises to which they are not lamiliar (i.e. animal markets and slaughterhouse). Sticks and occaslonally metal bars may be used Irresponslbly to drtue the animals causIng body injury ranging from supericlal con tusions to decp wounds (FAO/WHO. 2004). These wounds often serve as a portal of entry to microorganisms present on tbe skin or in the animal environment thus causing drsease (Altabarl, 2009; Buxton and fraser, 1977; Hudson, 1800 and TCMBF, 2005)

The mesophille bacterla identufled in thls study lall within the spectrum of bacterla commonly isolated from carcass surfaces (Gracey and Collens, 1809 and ICMGF, 2005). The mean numbers lsolated from the injured parts were eonstderably higher than those recovered from the corresponding unafrected surfaces. Histologlcally. the injured tissues showed congestion, edema, degenerative and necrotlc ehanges. Degeneratton was also seen In apparenty normal tissue contlguous with affeeted aneas. These tissne changes may be ascoclated with physicochemieal altera tuons whlch would lurnish a sultable mutcroenvironment for the multuplication and spread of mteroorgandsms. This eonstitutes a potential source of meat contamination spollage. More. over, some pathogenlc bacterla and rung have been identfled which could be of publle health signllicance (Altabar, 2009 and ICMSF, 2008). Economite losses artse [rom the total condemnation of carcasses on ac count of multiple injurtes and spreading suppurative infections.

In conclusions, eruelty to animals is disapproved in Islam and condemned by animal welfare organlzations all over the world. Vete rinary extension service is important in disseminating knowledge among animal owners about proper management and husbandry practices. Suttable battery eleetrodes could be designed and used safely and effectively in stead of sticks and other hard objeets to drive canncls, and thus avold unnecessary Ussue damage 
Table (1): Incidence and site of traumatic injuries in slaughtered camel carcasses.

\begin{tabular}{cccccccccc}
\hline $\begin{array}{c}\text { Total } \\
\text { No. }\end{array}$ & $\begin{array}{c}\text { No. } \\
\text { affected } \\
(\%)\end{array}$ & \multicolumn{2}{c}{ Thigh } & R & L & & & & \multicolumn{3}{c}{ Rite of injury and number $(\%)^{*}$} \\
& $(\%)$ & & & R & L & R & L \\
\hline 569 & 136 & 56 & 50 & 27 & 7 & 3 & 1 & 3 & - \\
& $(23.9)$ & $(41.2)$ & $(36.7)$ & $(19.9)$ & $(5.1)$ & $(2.2)$ & $(0.7)$ & $(2.2)$ & $(-)$ \\
\end{tabular}

11 animals had contusions in left and right thigh.

* \% of number affected. 
Tahle (2): Surfaces area $\left(\mathrm{cm}^{2}\right)$ of injured sites

\begin{tabular}{|c|c|c|c|c|c|}
\hline \multirow[b]{2}{*}{ Area $\mathrm{cm}^{2}$} & \multirow{2}{*}{$\begin{array}{c}\text { Surface } \\
\text { Thigh } \\
\text { No. }(\%)\end{array}$} & \multirow[b]{2}{*}{$\begin{array}{r}\text { Rump } \\
\text { No. (\%) } \\
\end{array}$} & \multicolumn{2}{|c|}{ Site of injury } & \multirow[b]{2}{*}{$\begin{array}{c}\text { Flank } \\
\text { No. }(\%) \\
\end{array}$} \\
\hline & & & $\begin{array}{c}\text { Hump } \\
\text { No. }(\%)\end{array}$ & $\begin{array}{r}\text { Thorax } \\
\text { No. }(\%) \\
\end{array}$ & \\
\hline$\geq 50$ & $45(42.45)$ & $12(44.44)$ & $1(14.29)$ & $1(25,0)$ & \\
\hline $50-100$ & $14(13.21)$ & $4(14.81)$ & $1(14.29)$ & $0(-\infty)$ & $3(100 \%)$ \\
\hline $101-200$ & $14(13.21)$ & $3(11.11)$ & $2(28.57)$ & $2(50,0)$ & - \\
\hline $201-300$ & $12(11.32)$ & $2(7.41)$ & $2(28.57)$ & $0(-)$ & \\
\hline $301-400$ & $5(4.72)$ & $2(7.41)$ & $0(-)$ & $0(-)$ & \\
\hline $401-500$ & $3(2.83)$ & $1(3.7)$ & $0(-)$ & $1(25.0)$ & \\
\hline $501-600$ & $2(1.89)$ & $2(7.41)$ & $0(-)$ & & \\
\hline $601-700$ & $3(2.83)$ & $0(-)$ & $0(-)$ & & \\
\hline $701-800$ & $7(6.60)$ & $0(-)$ & $1(14.28)$ & & \\
\hline $801-900$ & $1(0.94)$ & $1(3.7)$ & $0(*)$ & & \\
\hline Total & $106(100 \%)$ & $27(100 \%)$ & $7(100 \%)$ & $4(100 \%)$ & $3(100 \%)$ \\
\hline
\end{tabular}




\begin{tabular}{|c|c|c|c|c|c|}
\hline $\begin{array}{l}\text { Opinow } \\
\text { pur jsBon }\end{array}$ & $\because N$ & 吕 & 1 & vi & 05 \\
\hline 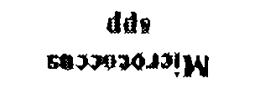 & $\neq 0$ & $\begin{array}{ll}0 & \infty \\
0 & 1\end{array}$ & $\stackrel{9}{9} \stackrel{0}{\text { in }}$ & $\Leftrightarrow \approx$ & $\stackrel{0}{=}$. \\
\hline $\begin{array}{c}\text { dds } \\
\text { sn|! }\end{array}$ & $\dddot{n} \underset{n}{n}$ & Si & 1 & 1,1 & ' 1 \\
\hline 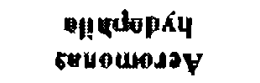 & 1 & 3. & 1. & $،$ & 19 \\
\hline 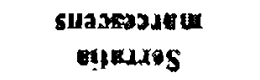 & $\stackrel{\infty}{\infty}$ & $\ddot{0} \overline{0}$ & 1 & $1 \quad r$ & 1 \\
\hline 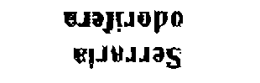 & o & ' 1 & 1 & , 1 & , 1 \\
\hline 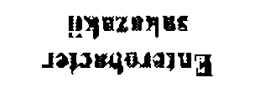 & S & . ' & 1 & .1 & ' \\
\hline 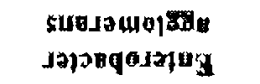 & is & $\vec{N} \overline{0}$ & $x \quad 4$ & 1 & 11 \\
\hline 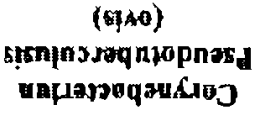 & $\underline{0}$. & 피, & 1 & $\stackrel{r}{\prime}$ & $1 \quad i$ \\
\hline x!d & $\bar{o} \cdot$ & 3. & 1 & ' & , 1 \\
\hline 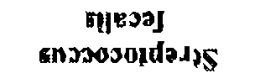 & $\underset{r \dot{v}}{0}$ & Dy & , 1 & $\cdot 1$ & $1 \quad 1$ \\
\hline 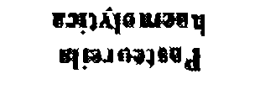 & 잉. & +1 & 11 & 1 & 1 \\
\hline 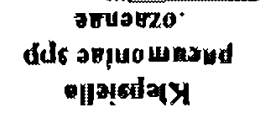 & Oי & \pm 1 & 1 & 11 & I 1 \\
\hline 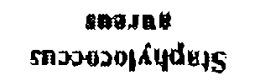 & $W_{0}^{\prime}$ & 1 & ' 1 & 11 & 1 \\
\hline $\begin{array}{l}\text { вboz!uy } \\
\text { भpuow|s }\end{array}$ & $\stackrel{0}{\circ}$. & $1 \quad 1$ & 1 & - $x$ & , ' \\
\hline 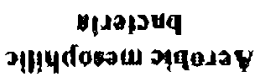 & 尽 & $\stackrel{9}{2}$ & $\stackrel{0}{=} \overrightarrow{0}$ & $\underset{⿱ 一 𫝀}{\infty}$ & 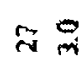 \\
\hline 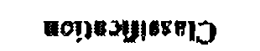 & $-=$ & $\neg$ 口 & $m=$ & $-\approx$ & 幽 \\
\hline $\begin{array}{l}\text { yus } \\
\text { supdwes }\end{array}$ & 홀 & $\frac{2}{2}$ & 볼 & 읍 & 5 \\
\hline
\end{tabular}




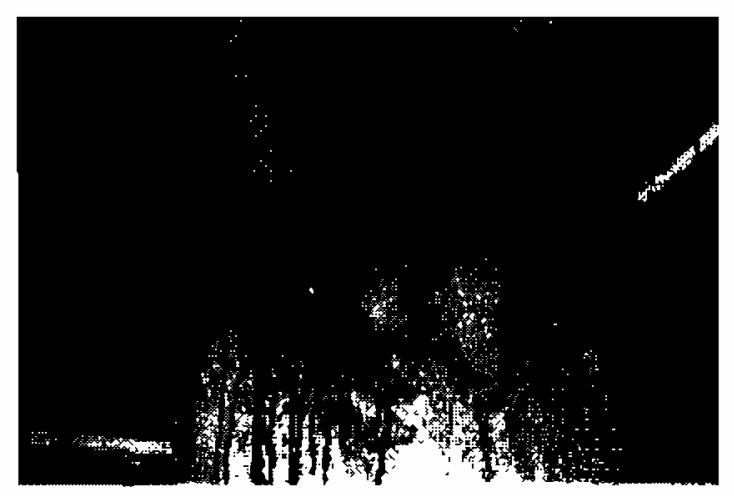

Fig. 1: Fecent Haemorrhagle contusion. Hght thigh.

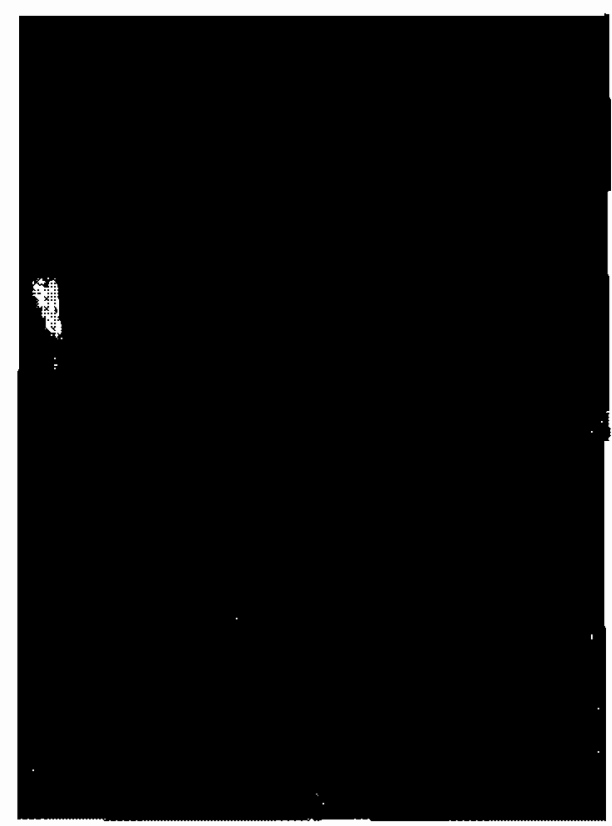

Fig. 3 : Abscess in sacral regfon.

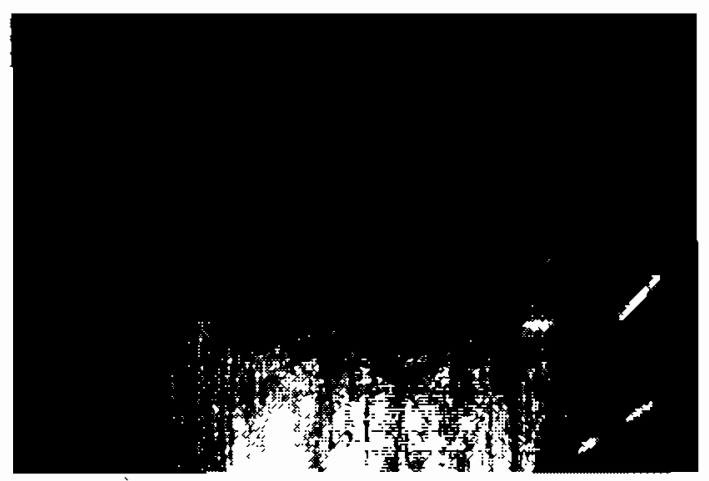

Fid. 2 : Muscles necrosis and edema. both thights.

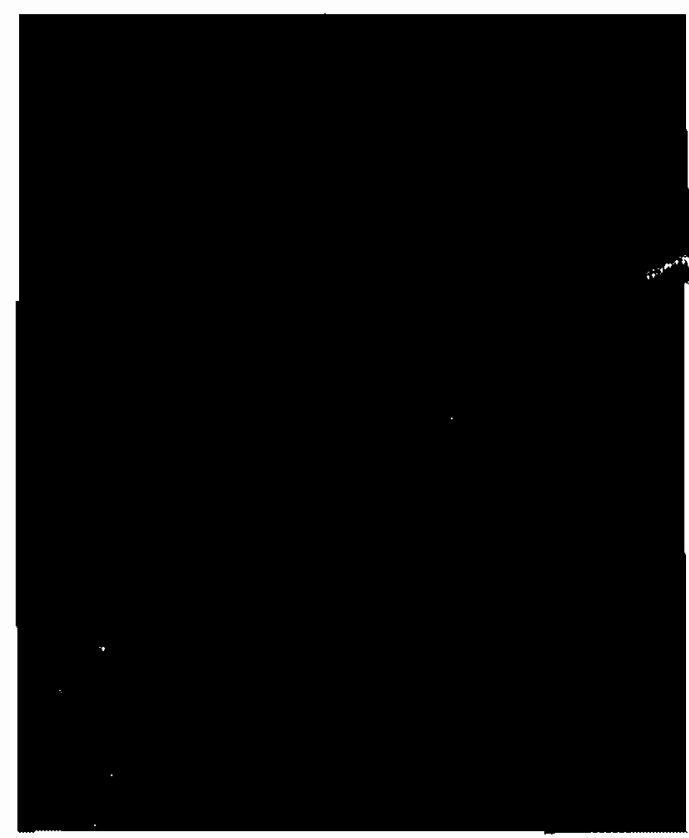

Fig. 4: Thigh contuslons and abscess In lumbo sacral reglon. 


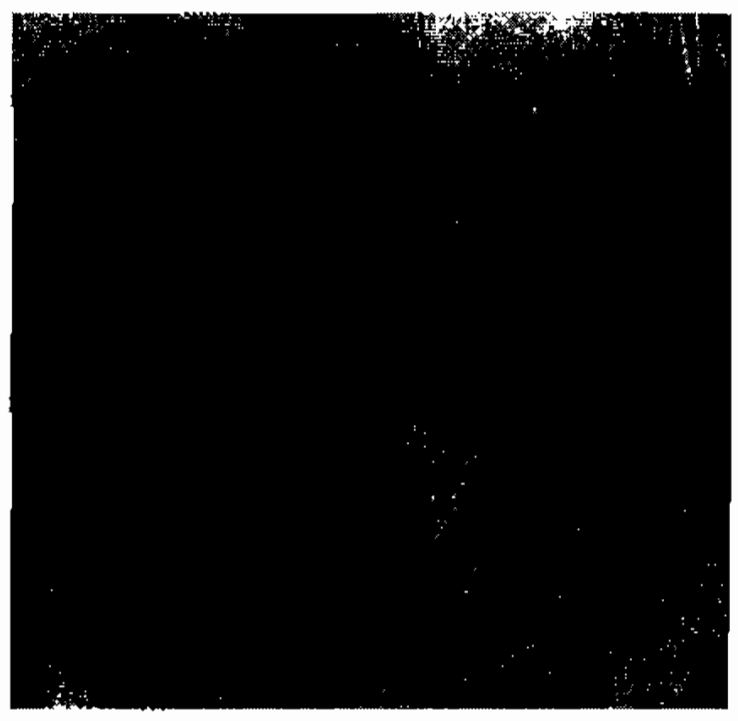

Fig. 5 : Traumattc fat necrosls in hunip.

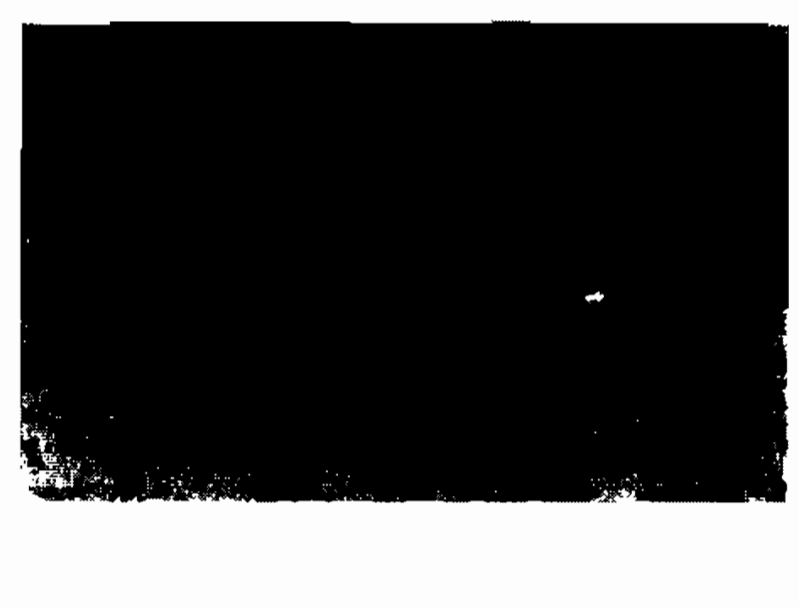

Fig. 6 : Skeletal muscle showing degeneration, edema and haemornhages. HE $x$ 80.

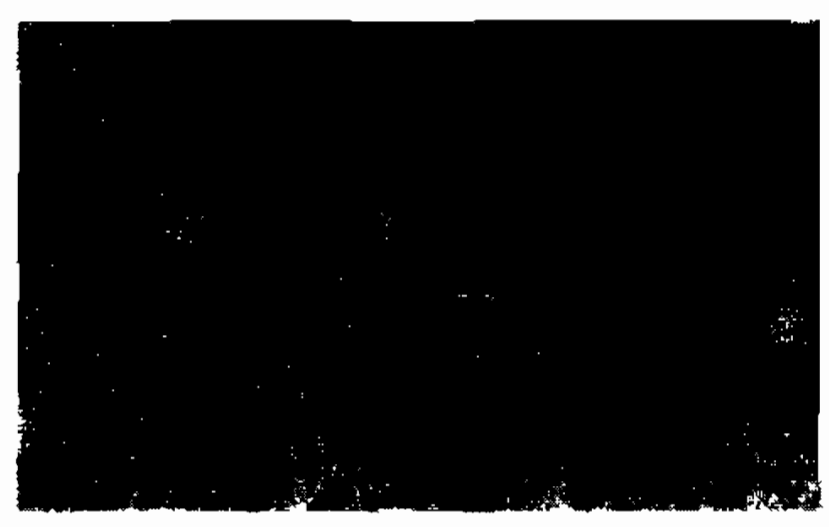

Fig. 7 : Muscle showing Suppurative myostHs. Note necrosts and fibrosls HE $x$ 160. 


\section{RPFERENCES}

Altabarl, G. (2000) : Meat Hyglene and safety, Ad-Ahsa Mundclpatty. 311 pgs.

Buxton, A and Fraser, G. (1977): Anlmal microblology, Vol. 1, ist Ed. Blackwell Sclentinc Publleations, Oxford. UK.

Downes, P. F. and Kelth, I. (2004) : Compendium of methods for the microblologlcal examiration of foods, chcesc repeater. Pub. $4^{\text {th }}$ ed.

Dwighte, H.; Lachlan, $\boldsymbol{N}$. J. and Richard, L. (2004) : Veterinary ratcroblology. $2^{\text {nid }} \mathrm{Ed}$. Blackwell Publishing.

Gracey, J. F. and Collns, D. S. (1099): Mcat Hyglene, $9^{\text {th }}$ ed. Ballicre Tinadall, London, Phlladelphia.

Gregary, N. G, and Grandin, T. (1908) : Antmal welfare and rneat science. CABI publishing, UKS.

Jay. J. M.; Loesener, J. M. and Golden, A. D. $(2006)$ : Modern food microblology $17^{\text {th }}$ Ed. Publisher Spriner.

FAO/WHO (2004) : Drall code of hyglenie for meat. Iu report of the $10^{\text {th }}$ Scssion of the Codex Committec on meat Hygiene.

Beganovic, A (1978) : Microbiologlya mesa 1 mesnilh preradevina, Univerz. Izd. Sarajevo.
Hudeon, W. R.; Mead. G. C. and Finton, M. H. (1996) : Relevance of abattotr hyglene assessment to microblal contamination of Brithsh beel carcasses. Vet. Rrc. $139: 587$ 589

ICMSF (internatlonw Commiasion on Macroblologleal speciflcatlons for foode) (2006) : Mlcroorganisms in food. $2^{\text {nd }} \mathrm{Ed}$. malcroblal ccology of food commodites, Kluwer Academic, Plenum Publishers, New York. USA

Jerzembeck, R. (1997) : Propleme des Hyglene und Techruk der Mechantshe Enthautung von RIndern 3: 76.

Koneman, W. E.; Alen, D. S, Dowell, R. V.; Hextert. $M$. and Sommera, J. $B$. (19日2) : Diagnostic micrablology. Luppincalt Company Phlladdphla. St, Lowis, London, Sao Poulo, New York, Sydney.

MeGavin, M. D.; Carlton, W. W. and Zachary. F. J. (2001) : Thomsor's Speclal Vetcrinary Pathology. 3Td Ed. Mosby, Inc.. St. Louls, London, Phlladelphla, Sydney, Toronto.

Speck, L. (1904): Compendlum of meth ods for the microblologlcal examination of Soods $2^{\text {nd }}$. Ed. American Publle Health assoclation, Washington.

Wilson G. W, (2005) : Wilson_s practical meat Inspection, $\gamma^{\text {th }}$ Ed. Blackwell Publishing. 